\title{
4. 种経症状に着目した撮影法
}

国立精神・神経センター ○立道信宏 真壁正二 最高裁診源所岸幹幸 三楽病院佐藤光正 電通医務室 八重沢 幸平高島屋医務室 小森福夫 戸田中央病院 山口広

(目的)痛みなとの症状を訴えている患者さんの声を閭き神経学的知識のもとに撮影法に反映させ、従来のretrospectiveな㛟索対象としての情報提供から一歩踏み込んだより精度の高いX 楾像を提供すべきであると考えます。 (方法)䁚部領域において、神経学的デルマトームに対応させ、目的神経支配部を判断し撮影にあたりました。ま た、画像評洒に客䚒性を持たせるため自作モデルと人体骨格標本を用い、各項目より㭲討評価を加えた。 (結果)(1椎体自体の重なりが極力避けられた。(2)Disc spaceの正確な把握が可能でした。またpincer's mechani一 smの存在し㧹る状況把握が可能でした。(3)目的椎間孔に合わせるため椎間孔内に描出されるspur formationなど 複败な状態把握が正確に行えました。

\section{5. 着衣時の骨振影について腰椎維

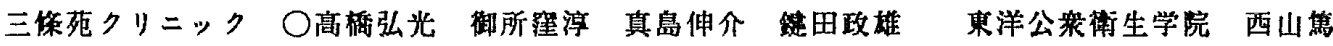

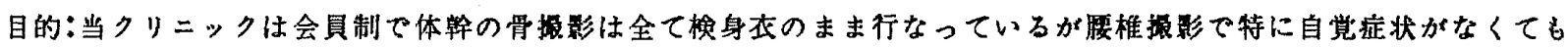
写真上、下部腰椎に異常像を示す率が高いので今回は着农搰影で主に該部の正確な側位写真を得る方法を発表する。

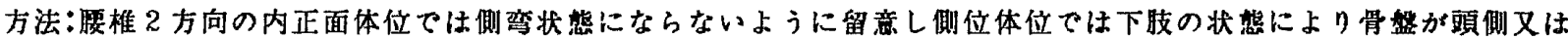

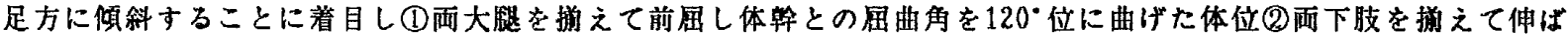
した自然体位(3)下方の肢は䐂を軽く曲げをせ上方の滕は伸ばした体位、3つの体位の使い分けは個人差を考唇した。

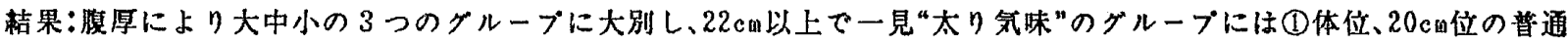

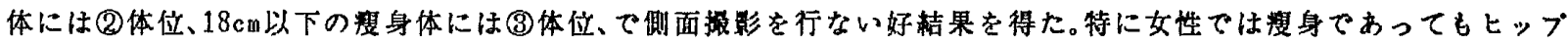

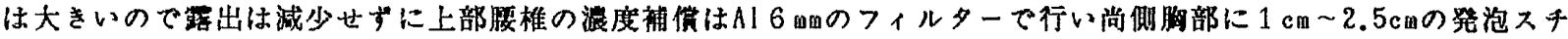

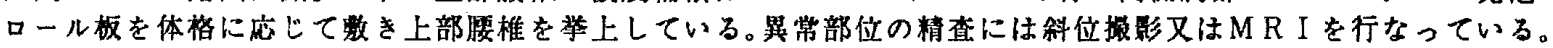

\section{6. 胸部撮影用感度補償增感紙の臨床応用}

熊大医短 ○東田善治 熊大中放 勝田昇 高橋睦正 国立熊病 荒朴不次男 東芝横浜金属 中村光夫

第42回および 43 回日放技学会総会て、胸部撮影用感度補償増感紙の基本特性について報告した。今回は、補偵 增感紙の臨床応用について報告する。対象として、補嗩增感紙と通常增感紙て撮影した約 70 例の胸部X線写真を用 いた。こ㧈らの写真を 3 名の放射線科医が独立に読影し、補僧增感紙の有用性について検討した。読影は、肺野およ び鯆隔部に含まれる臟器の描出能について行ない。3名の読影結果を平均した。

結果として、補償增感紙を利用することにより、胸部X線写真中に含まれる各種㙎器の描出能が著しく改善した。

\section{7. 略部ボータブル㧹影における I ON CHANBER・AECの有用性。(第一報)}

下谷病院 放射線科 O山崎雅代 浜野純行 雨宫伸司 大石真砂美 杉㴊建造

目的）当院では、昭和62 年 4 月シーメンス社のポータブル装置“モビット”とその付属器として“I ON C H A NBER・AEC”索使用したところ、準高圧で安定した画像が得られ、又どんな体曆の被写体で同濃度の再現性の 良い画像がえられるなど画像の向上とそれと同時に再撮影染の低下もみられたので、報告します。

方法）1。撮影条件：グリットを使用して、一般撮影と同じ準高圧にした。2。濃度：気管分岐部、心綎部、肺野の 测定。3: 再撮影萃とそ0)分析。

結果）IONCHANBER・AECの使用により、術者の経験にかかからず均一な画像が得られ、準高圧でもその 性能は良好であった。濃度の均一化は、再撮影を践少させ、画像診断や臨休においても経過観察に得に有效であると 考えられる。色々な面で、まだまだ末知数が多く今後さらに研究市、画你间上、撮影の简易化などに寄与していきた いと思う。 